\title{
IHL and Human Rights Law: Relationship*
}

\section{Christine Byron*}

\section{Introduction}

We need to start by asking ourselves why the relationship between International Humanitarian (IHL) and Human Rights (HR) law matters. Partly this is because these two areas of law overlap and deal with the same subject matter to some extent and partly it is because issues of human rights in times of conflict are being dealt with by human rights bodies. ${ }^{1}$ Although many reasons have been suggested for this development, from people becoming more litigious, to encouragement from lawyers in countries at war, Henkaerts suggests that this "trend is largely due to victim's search for a forum in order to obtain remedies for violations of their rights during armed conflict". ${ }^{2}$ This is essentially because of a lack of individual petition in IHL. ${ }^{3}$ Therefore, as a result of the overlapping subject matter and the fact that human rights bodies are having to deal with this issue it is important to deal with the relationship between the two areas of international law.

First, the article will look at the similarities between IHL and HR, demonstrating the similarities of subject matter, then the differences between the two, which starts to explain the tension between the two areas of international law, despite the impact that the two areas have had on each other. Secondly, the influence that the two fields have had on each other despite their differences will be considered. Thirdly, the lex specialis doctrine of international law will be discussed, including the approach of the ICJ and whether this is really a simple way to

\footnotetext{
* Based on a paper given at the 'Victims of armed conflict at the juncture of international humanitarian law and human rights law' at the Ministry of Foreign Affairs and Trade, Budapest, Hungary.

* Lecturer in Law, Cardiff University.

${ }^{1}$ A Orakhelasvili: The interaction between human rights and humanitarian law: fragmentation, conflict, parallelism, or convergence? European Journal of International Law Vol 19 (2008) 161-182, pp.161-162 considers 'whether their requirements conflict with each other or whether they develop towards forming the common legal ground for the protection of individuals in the context of an armed conflict'.

2 J Henkaerts: Concurrent application of international human rights law and international humanitarian law: victims in search of a forum. Human Rights and International Legal Discourse Vol 1 (2007) 95-124, p.97, see also P. Eden and M. Happold: Symposium: The relationship between International Humanitarian Law and International Human Rights Law. Journal of Conflict and Security Law Vol 1 (2010) 441-447 p.441 and M Milanovic: A norm conflict perspective on the relationship between international humanitarian law and human rights law. Journal of Conflict and Security Law Vol 1 (2010) 441-447 p.460.

${ }^{3}$ J Henkaerts: $\mathrm{n} 2$ supra, p.104 and see C Droege: Elective affinities? Human rights and humanitarian law. International Review of the Red Cross Vol 9 No 871 (2008) 501-547 p.543 and see C Byron: A blurring of the boundaries: The application of international humanitarian law by human rights bodies. Virginia Journal of International Law Vol 47 (2007) 839-896 pp. 842-847.
} 
deal with the tension between the two areas of law. The article will conclude by considering that the nature of the conflict may make a difference between which of the two areas of law has the greatest influence. Finally, some of the benefits and problems of applying IHL and HR in the same situation will be discussed.

\section{$\underline{\text { Similarities and Differences between IHL and HR Law }}$}

\section{Similarities}

The Inter-American Commission of Human Rights has described IHL and Human Rights as having a "common nucleus of non-derogable rights and a common purpose of protecting human life and dignity", ${ }_{4}^{4}$ and Louise Doswald Beck and S. Vite agree that generally IHL "is now less perceived as a code of honour for combatants than as a means of sparing noncombatants as much as possible from the horrors of war"5

Both human rights law and humanitarian law are based on the premise that the protection accorded must be without any discrimination. See for example in human rights law: Article 2(1), ICCPR "Each State Party to the present Covenant undertakes to respect and to ensure to all individuals within its territory and subject to its jurisdiction the rights recognised in the present Covenant without distinction of any kind, such as race, colour, sex, language, religion, political or other opinion, national or social origin, property, birth or other status". 6 Article 14, ECHR "the enjoyment of the rights and freedoms set forth in this Convention shall be secured without discrimination on any ground such as sex, race, colour, language, religion, political or other opinion, national or social origin, association with a national minority, property, birth or other status".7

And in IHL:

Article 16, GCIII "all prisoners of war shall be treated alike by the Detaining Power, without any adverse distinction based on race, nationality, religious belief or political opinion, or any other distinction founded on similar criteria". 8

\footnotetext{
${ }^{4}$ Coard et al $v$ United States, Inter-American Commission of Human Rights, Case 10.951, Report No109/99, 29 September 1999, para 39

${ }^{5}$ L Doswald-Beck and S. Vité: International humanitarian law and human rights law. International Review of the Red Cross Vol 33 Issue 293 94-119 p 105.

${ }^{6}$ International Covenant on Civil and Political Rights, 999 UNTS 171.

${ }^{7}$ European Convention for the Protection of Human Rights and Fundamental Freedoms, COE Treaty No 005.

${ }^{8}$ Geneva Convention III Relative to the Treatment of Prisoners of War, 75 UNTS 135.
} 
Article 27, GCIV "all protected persons shall be treated with the same consideration by the Party to the conflict in whose power they are, without any adverse distinction based, in particular, on race, religion or political opinion". 9

On a superficial level, both IHL and HR are multi-lateral treaties ratified by States and binding upon them. ${ }^{10}$ However, as Cassimatis points out, both regimes contain peremptory norms - although he also fears that "the similarities between the regimes appear to ensure overlapping operations and greater scope for conflict" between them. ${ }^{11}$

\section{Differences}

This perhaps leads on to the differences between IHL and HR:

HR treaties set out rights that all individuals have by virtue of the fact that they are human unlike IHL treaties which often only protect certain categories of individuals such as 'POW's' or 'Civilians' - and GCIV only the latter when they are 'protected persons' so explicitly excluding a State's own citizens. This is, in essence a difference in philosophy, which has been termed an "ideological incompatibility". ${ }^{12}$

Human Rights Laws are binding only upon States in respect of individuals within their jurisdiction but IHL is not only binding upon a State in its relationship with other States and their citizens, but is also binding upon individual soldiers/civilians who may be liable for war crimes if they breach IHL during a conflict. ${ }^{13}$ It is important to note that the basis of human rights law is to protect persons within the State's territory and jurisdiction from abuse by that State. Whilst there can be State Responsibility for breaches of IHL, there cannot be individual responsibility for breaches of HR.

When I spoke about similarities between IHL and HR, I spoke about the relatively superficial concept that they were both multilateral treaties. Nevertheless, HR treaties can be either

\footnotetext{
${ }^{9}$ Geneva Convention IV Relative to the Protection of Civilian Persons in Time of War 75 UNTS 287. See L Doswald-Beck and S. Vité, n 5 supra for a similar comment pp.107-108.

${ }^{10}$ B Bowring: Fragmentation, Lex Specialis and the Tensions in the Jurisprudence of the European Court of Human Rights. Journal of Conflict and Security Law Vol 14 (2010) 485-498 p.489,

${ }^{11}$ A Cassimatis: International humanitarian law, international human rights law and fragmentation of international law. International and Comparative Law Quarterly Vol 56 (2007) 623-639 p.628.

${ }^{12}$ P Eden and M Happold, n 2 supra p.444.

${ }^{13}$ D. Kretzmer: Rethinking the application of IHL in non-international armed conflicts. Vol 42 Israel Law Review Vol 42 (2009) 8-45 p.14.
} 
universal in scope or regional. Indeed, one of the most advanced regional treaties is the ECHR - the subject of the next presentation. However, there is no such concept in modern IHL - treaties are always open to all States for ratification - they are intended to be universal in application. There is no such thing as 'European IHL' for example!

Human Rights treaties are mainly split between civil and political rights - such as the right to life, prohibition against torture, freedom of speech, - and economic, social and cultural rights - such as the right to education, right to highest attainable standard of health and the right to an adequate standard of living. IHL is not divided in such a way and, for example, the Geneva Conventions protect both rights of the former category, such as freedom from torture and of the latter such as duty to ensure that the supply of food and medicine in occupied territories is adequate.

Although IHL and HR use some of the same language, such as the word, 'proportionality', nevertheless it means different things. In IHL the concept of the principle of proportionality is that civilian casualties and damage to civilian property must not be excessive compared to the military advantage anticipated. In HR the concept of proportionality in using potentially lethal force is a strict concept of proportionality in which the right to life of the person causing the use of force is to be considered and protected as much as possible as well as that of innocent civilians. ${ }^{14}$

Kretzmer comments that IHL "originally rested on assumptions of symmetry and reciprocity", noting that the former means that IHL applies to both sides of the conflict and the later meaning that both parties employ IHL in the same way. ${ }^{15}$ He notes that the 1907 Hague Convention on Laws and Customs of War on Land and attached Regulations only applied if all parties to the conflict were also parties to the convention. He mentions that although the 1949 Geneva Conventions would continue to bind the parties to a conflict interse, they would not bind the relationship between those parties and non-parties to the GCs who were involved in the conflict. ${ }^{16}$ Whilst the advent of customary international law and the acknowledged customary status of the 1907 Hague Regulations and the 1949 Geneva

\footnotetext{
${ }^{14} \mathrm{R}$ Cryer: The interplay of human rights and humanitarian law: the approach of the ICTY. Journal of Conflict and Security Law Vol 14 (2010) 511-527 p.514 and see C Byron, n 3 supra pp. 855-856 and see also D Kretzmer, n 13 supra p.26-28

${ }^{15}$ See also C Droege on this, $\mathrm{n} 3$ supra p.503.

${ }^{16}$ D. Kretzmer, n 13 supra, p.12.
} 
Conventions make this issue moot - the fact is that the original method of enforcing IHL is belligerent reprisals - taken by one of the parties to an armed conflict in response to another parties' violation of IHL. Reprisals were limited by the 1949 Geneva Conventions and greatly restricted by 1977 Additional Protocol 1. Nevertheless, HR law is seen as protecting those within the territory and jurisdiction of a State independent of whether another State party violates HRs in its treatment of its own citizens. There is no concept of any method of restoring international legality other than protesting and if available, taking them to a human rights forum. The State offended by the lack of application of HR by another State, certainly cannot stop applying HRs to those in its own territory and jurisdiction.

\section{The Impact of HR on IHL and Vice Versa}

\section{HR influenced by IHL}

The most well-known influence of IHL on HR relates to children, the Convention on the Rights of the Child. ${ }^{17}$ It defines children in Article 1 as being under 18, rather than 15 as is more normal under IHL, however in article 38 influenced by IHL it refers to the age of 15 . It requires States Parties to "respect and ensure respect" for the rules of IHL applicable to them in an armed conflict, relevant to the child and then in its prohibition of the use of child soldiers essentially replicates Article 77 of Additional Protocol I. ${ }^{18}$ Finally it requires States Parties "in accordance with their obligations under international humanitarian law to protect the civilian population in armed conflicts" to "take all feasible measures to ensure protection and care of children" affected by an armed conflict. This demonstrates clearly the point that some human rights treaties envisage applying at all times including during an armed conflict.

The Optional Protocol to the Convention on the Rights of the Child on the involvement of children in armed conflict intended to raise the minimum age for taking "a direct part" in the hostilities of an armed conflict to $18 .{ }^{19}$ Nevertheless, it did not prohibit voluntary recruitment into the armed forces, with parental consent, presumably in line with Article $1 .^{20}$

\footnotetext{
${ }^{17}$ Convention on the Rights of the Child, 1577 UNTS 3.

${ }^{18}$ Protocol Additional to the Geneva Conventions of 12 August 1949, and Relating to the Protection of Victims of International Armed Conflicts (Protocol I), of 8 June 1977, 1125 UNTS 609.

${ }^{19}$ Article 1, Optional Protocol to the Convention on the Rights of the Child on the involvement of children in armed conflict, 25 May 2000, 2173 UNTS 222.

${ }^{20}$ See Article 3 of the Optional Protocol to the Convention on the Rights of the Child. Note that the UK still recruits into the armed forces from 16 years old as the Committee on the Rights of the Child comments in concern as part of its Concluding Observations on the fifth periodic report of the United Kingdom of Great Britain and Northern Ireland "The minimum age for voluntary recruitment as 16 years has not been changed and
} 
Article 4(1) of the Optional Protocol is particularly interesting as it seems to address itself to non-state actors. Whilst there is discussion about the extent to which non-State actors have the responsibility to comply with human rights law, ${ }^{21}$ the Committee on the Rights of the Child, similarly to other human rights bodies, does not have the authority to deal with nonState actors. ${ }^{22}$ Perhaps that is the reason for Article 4(2) which requires State Parties to take all feasible measures to prevent recruitment and use of non-State actors of children "including the adoption of legal measures necessary to prohibit and criminalize such practices". It is also interesting that Article 5 specifically states that if IHL is more conducive to the rights of the child then it shall apply, rather than the Optional Protocol.

Human rights conventions may be derogated from in times of emergency threatening the life of the nation. However, all the main conventions allowing derogation include a very similar phrase: that they can only derogate "provided that such measures are not inconsistent with their other obligations under international law". ${ }^{23}$ Whilst this will naturally refer to other human rights instruments, it also clearly can refer to international humanitarian law. ${ }^{24}$

\section{IHL influenced by $H R$}

The 1977 Additional Protocols are particularly influenced by HR. ${ }^{25}$ AP1, Article 72 with reference to the field of application of that section states that the provisions of that section are in addition to "other applicable rules of international law relating to the protection of fundamental human rights during international armed conflict". ${ }^{26}$ Article 75 on fundamental guarantees is clearly influenced by human rights law.

child recruits makes up 20 per cent of the recent annual intake of United Kingdom Regular Armed Forces”, 12 July 2016, UN Doc. CRC/C/GBR/CO/5.

${ }^{21}$ See A Clapham: Human Rights Obligations of Non-State Actors. Oxford, Oxford University Press 2006, in particular pp.25-58 and 271-316. C Droege, however confirms that currently the application of human rights to non-state parties to a conflict is "controversial", n 3 supra p. 521.

${ }^{22}$ See comments of C Droege, n 3 supra p. 537.

${ }^{23}$ Taken from the ICCPR, Article 4, similar expressions are to be found in the ECHR, Article 15 and the American Convention on Human Rights, 22 Nov 1969, OAS Treaty Series n 36, Article 27.

${ }^{24}$ A. Cassimatis, n 11 supra p. 634.

${ }^{25}$ C Droege, n 3 supra p. 506.

${ }^{26}$ Charles Garraway: To kill or not to kill? - Dilemmas on the use of force. Journal of Conflict and Security Law Vol 14 (2010) p.501 and see A Cassimatis, n 11 supra p. 634 and J Henkaerts, n 2 supra p. 123. 
The preamble to APII recalls that "international instruments relating to human rights offer a basic protection to the human person", ${ }^{27}$ which Garraway suggests "clearly envisages the coexistence of the two legal systems", ${ }^{28}$ The fundamental guarantees in Articles 4 and 6 are clearly influenced by human rights law. Indeed, at a fundamental level, Common Article 3 of the 1949 GCs, in dealing with how a State had to deal with those in rebellion to it was revolutionary at the time and was more reminiscent of the human rights law which was developing in the post ww2 environment. ${ }^{29}$ As Hill-Cawthorne comments that "the premise underpinning both IHRL and the law of non-international armed conflict is, after all, that it is the relationship between a State and its nationals that is to be regulated". 30

\section{$\underline{\text { The ICJ and Lex Specialis }}$}

Often presentations on IHL mainly, but not only, by military lawyers, dismiss HR with the phrase 'in an armed conflict IHL is lex specialis to HR and so we only need to consider IHL'. Before commenting on this all-too common expression, I want to first briefly discuss the ICJ cases where they dealt with the relationship between IHL and HR.

In its Advisory Opinion on the Legality of the Threat or Use of Nuclear Weapons the International Court of Justice (ICJ) noted that the ICCPR did not cease in time of war, except to the extent that it had been derogated from in a time of national emergency but noted that right to life was non-derogable and so

"In principle the right not arbitrarily to be deprived of one's life applies also in hostilities. The test of what is an arbitrary deprivation of life, however, then falls to be determined by the applicable lex specialis, namely the law applicable in an armed conflict which is designed to regulate the conduct of hostilities". ${ }^{31}$

Milanović comments that this judgment "did not really examine the relationship" between IHL and HR in abstraction, but was actually looking at one particular human rights norm, the

\footnotetext{
${ }^{27}$ Protocol Additional to the Geneva Conventions of 12 August 1949, and relating to the Protection of Victims of Non-International Armed Conflicts (Protocol II), 8 June 1977, 1125 UNTS 609.

${ }^{28}$ C Garaway, n 26 supra p. 501.

${ }^{29}$ D Kretzmer, n 13 supra p. 20.

${ }^{30}$ L Hill-Cawthorne: Humanitarian law, human rights law and the bifurcation of armed conflict. International and Comparative Law Quarterly Vol 64 (2015) 239-325 pp. 300-301.

${ }^{31}$ Legality of the Threat or use of Nuclear Weapons, Advisory Opinion of 8 July 1996, ICJ Reports 1996 p. 226 at para. 25.
} 
right to life, as it is phrased by the ICCPR, "It was these specific rules that were held to be lex specialis, in that they could help interpret the 'arbitrary' part of Article 6 ICCPR in times of armed conflict". 32

In its Advisory Opinion on Legal Consequences of the Construction of a Wall in the Occupied Palestinian Territory, the ICJ considered further the relationship between IHL and human rights. ${ }^{33}$ First, it reiterated that human rights continue in an armed conflict, ${ }^{34}$ before going on to discuss the possible types of relationship between IHL and HR.

"some rights may be exclusively matters of international humanitarian law; others may be exclusively matters of human rights law; yet others may be matters of both these branches of international law In order to answer the question put to it, the Court will have to take into consideration both these branches of international law, namely human rights law and, as lex specialis, international humanitarian law." 35

This case may be criticised as it seems to be making a general claim about lex specialis and may have been influenced by the Human Rights Committee General Comment Number 31 which was adopted only a couple of months earlier and said that "While, in respect of certain Covenant rights, more specific rules of international humanitarian law may be specially relevant for the purposes of the interpretation of Covenant rights, both spheres of law are complementary, not mutually exclusive". ${ }^{36}$ Milanović states that "this may be perfectly true, but is equally unhelpful in providing practical solutions". 37

In the Case Concerning Armed Activities on the Territory of the Congo (DRC v Uganda) the Court held that Uganda was responsible for the violations of HR and IHL committed by its forces and "for failing to comply with its obligations as an occupying Power in Ituri in respect of violations of international human rights law and international humanitarian law in

\footnotetext{
${ }^{32}$ M. Milanović, n 2 supra p. 463, original emphasis.

${ }^{33}$ Legal Consequences of The Construction of a Wall in the Occupied Palestinian Territory, Advisory Opinion of 9 July, ICJ Reports 2004, p. 136.

${ }^{34}$ Ibid., para. 106.

35 Ibid.

${ }^{36}$ Human Rights Committee, General Comment No. 31, The Nature of the General Legal Obligation Imposed on States Parties to the Covenant Adopted on 29 March 2004, UN Doc. CCPR/C/21/Rev.1/Add. 13, para. 11 and see comment of N Prud'homme: Lex specialis: oversimplifying a more complex and multifaceted relationship? Israel Law Review Vol 40 (2007) 356-395 p.384.

${ }^{37}$ M. Milanović, n 2 supra p. 464.
} 
the occupied territory". ${ }^{38}$ Orakhelashvili comments that this case shows parallelism between the two areas of law, confirming that "the two bodies of law not only apply in the same situations, but can also outlaw the same conduct" and the findings of the Court "constitute a warning that even if the protection in one of the fields is found to be less than in the other field, the applicability of the latter will thus not be prevented". ${ }^{39}$ Schabas points out that the ICJ did not address a possible conflict between IHL and HR in this case but "treated them as two complementary systems, parts of a whole". ${ }^{40}$

Not everyone thinks that the ICJ has clarified matters here. Scobbie comments that having dealt with the issue 3 times one would have wished "that the Court might have been a little more candid and a bit more specific" although they have nevertheless "entrenched the idea that legally there is some normative relationship between these two branches of law". ${ }^{41}$ Schabas explains that the ICJ did not actually apply lex specialis to decide any of the cases above. $^{42}$ As he comments, in the Nuclear Weapons case the ICJ did not decide based on IHL but said that it could not exclude using the weapons in an extreme case of self-defence. ${ }^{43}$ In the Wall and Armed Activities on the Territory of the Congo cases "the ICJ treated the two bodies of law, without even considering whether one or the other should prevail" and so decided all three cases without really applying lex specialis "in determining the core issues" at all. ${ }^{44}$ As for the presentations which dismiss HR in the first sentence because lex specialis makes everything clear, Milanović rightly comments that lex specialis "must be abandoned as a sort of magical two-word explanation of the relationship between IHL and IHRL, as it confuses far more than it clarifies". ${ }^{45}$ Prud'homme goes further and states simply that "the theory of lex specialis is an inadequate model for the articulation of the parallel application of international humanitarian law and international human rights law". ${ }^{46}$

\footnotetext{
${ }^{38}$ Case Concerning Armed Activities on The Territory of the Congo (Democratic Republic of the Congo $v$. Uganda) Judgment of 19 December 2005, ICJ Reports 2005, p.168 at para. 220.

${ }^{39}$ A. Orakhelashvili, n 1 supra p. 163

${ }^{40}$ W Schabas: Lex specialis? Belt and suspenders? The parallel operation of human rights law and the law of armed conflict, and the conundrum of jus ad bellum. Israel Law Review Vol 40 (2007) 592-613 p. 597.

${ }^{41}$ I Scobbie: Principle or pragmatics? The relationship between human rights law and the law of armed conflict. Journal of Conflict and Security Law Vol 14 (2010) 449-457 p. 452 and see N Prud'homme, n 36 supra p. 378 stating that the ICJ "failed to provide a framework capable of clarifying the interplay" between IHL and HR.

${ }^{42}$ W Schabas, n 40 supra p.597.

43 Ibid.

${ }^{44}$ Ibid.

${ }^{45}$ M. Milanović, n 2 supra p. 462.

${ }^{46}$ N Prud'homme, n 36 supra p.386.
} 
So do the ICJ cases tell us about the relationship between IHL and HR? I think that first of all, we must remember that the ICJ can apply any relevant treaty law or customary law applicable to the situation before it. ${ }^{47}$ As there is no IHL body (international criminal law bodies are somewhat different) to deal with situations of armed conflict, conflict situations where military lawyers would automatically look to IHL are being examined by HR bodies and so it is not surprising that they examine the situation through the prism of HR. ${ }^{48}$

\section{Does the Relationship between IHL and HR depend upon the Nature of the Conflict?}

The law of international armed conflict is far more detailed than human rights law on many issues that arise in armed conflict, with the four Geneva Conventions applying and, depending upon ratification, Additional Protocol I. Nevertheless, as Sassòli and Olson make clear, even if IHL applies, human rights law "remain present" in the background. ${ }^{49}$ The example they give is that they "require an inquiry be conducted whenever a person has been deliberately killed", ${ }^{50}$ though this would be unlikely to apply during the actual conflict phase. However, in the occupation phase of the British armed conflict in Iraq, Al-Skeini $v$ UK, found that there had not been an effective investigation of five of the six Iraqis killed during that time, as required by Article 2 of the ECHR, even though "the procedural duty under Article 2 must be applied realistically, to take account of specific problems faced by investigators" because the UK was an occupying power in a foreign and hostile region in the immediate aftermath of invasion and war. ${ }^{51}$ They emphasised the need for an independent and effective investigation into deaths because the UK was an Occupying Power. ${ }^{52}$

Roberts discusses the "grounds for viewing international human rights law as applicable to occupations, including prolonged ones" and comments that some parts of HR law usefully supplement The Hague and Geneva Conventions, giving the examples of "prohibitions of

\footnotetext{
${ }^{47}$ Statute of the International Court of Justice attached to the Charter of the UN, see Article 38.

${ }^{48}$ See C Droege comment on this and on the influence of HR case law on IHL, n 3 supra p. 540.

${ }^{49} \mathrm{M}$ Sassòli and L Olson: The relationship between international humanitarian and human rights law where it matters: admissible killing and internment of fighters in non-international armed conflicts. International Review of the Red Cross Vol 90 issue 871 (2008) 599-627 p. 615.

${ }^{50}$ Ibid.

${ }^{51}$ Al-Skeini and Others v. The United Kingdom, Application No. 55721/07, Judgment, Grand Chamber Strasbourg 7 July 2011 para. 168 and 169-177.

52 Ibid., para. 169.
} 
discrimination in education and of racial discrimination generally". ${ }^{53}$ Lubell goes as far as to say that the concept of the applicability of human rights law during an occupation is "presumed" by, although he argues for "the precise requirements necessary to fulfil the obligation, and any assessment of whether they have been adhered to, must proceed based on a contextual approach". ${ }^{54}$ Meron comments on how human rights has infused IHL with more humanitarianism and gives the concrete example from the law of international armed conflict of the obligation to return prisoners of war to their own country without delay after the end of active hostilities. ${ }^{55} \mathrm{He}$ states that "Interpretation has drastically modified its [Article 118, Geneva Convention III] categorical language, steering it to respect for individual autonomy" and moving repatriation of prisoners of war to a right of free choice. ${ }^{56}$ This change clearly came about because of the influence of human rights law.

Before discussing the influence of human rights law upon non-international armed conflicts and noting the difference between the two types of conflict, an important issue that human rights bodies may struggle to understand is the difference between international armed conflicts and non-international armed conflicts. Meron stated that "Distinguishing between international and noninternational conflicts is particularly difficult in contemporary conflict situations, which often present aspects of both". ${ }^{57}$ Hampson comments that there are "a wide variety of situations in which the classification of a conflict as international or noninternational may give rise to difficulties" especially for human rights bodies and gives the examples of the conflict in Lebanon in 2006 as one which has elements of both international, Lebanon and non-international Hezbollah and asks if it was two conflicts or one and, if the latter, which type of conflict was it? ${ }^{58}$

The situation in non-international armed conflicts with respect to human rights law has a complex history. An initial issue is the difficulty of deciding whether a situation is a conflict

\footnotetext{
${ }^{53}$ A Roberts: Prolonged military occupation: The Territories since 1967. American Journal of International Law Vol 84 (1990) 44-103 p.97.

${ }^{54}$ N Lubell: Human Rights obligations in military occupation. International Review of the Red Cross Vol 94 issue 885 (2012) 1-21 p. 21 and see V Koutroulis: The application of international humanitarian law and international human rights law in situation of prolonged occupation: only a matter of time? International Review of the Red Cross Vol 94 issue 885 165-205 p.205.

${ }^{55}$ T Meron: The humanization of humanitarian law. American Journal of International Law Vol 94 (2000) 239278 p. 254, referring to Article 118 of Geneva Convention III Relative to the Treatment of Prisoners of War.

${ }^{56}$ Ibid., p. 256.

${ }^{57}$ Ibid., p.261.

${ }^{58}$ F Hampson: The relationship between international humanitarian law and human rights law from the perspective of a human rights treaty body. International Review of the Red Cross Vol 90 issue 871 (2008) 549572 p. 556.
} 
or has not reached that point. Hampson comments that characterising the 'Troubles' in Northern Ireland is difficult questioning whether the terrorist attacks carried out by armed groups were "sporadic, and therefore outside Common Article 3, or do sporadic attacks over a long period constitute protracted armed violence?". 59 Both Hampson and Droege comment upon the problem that a State denial that there is a non-international armed conflict on its territory can result in a human rights body in applying pure human rights law, Droege stating that "human rights bodies can often simply ignore humanitarian law because states have not acknowledged that they are involved in an armed conflict", ${ }^{60}$ to which Hampson points out that this "denies the applicability of IHL as a matter of law. It is not a matter of choice". ${ }^{61}$

In recent history there has been a push to expand the paucity of the treaty law in noninternational armed conflicts through customary international law, this was particularly notable in the Tadic Interlocutory Appeal Decision, where customary international law was invoked after commenting that a "State-sovereignty-oriented approach has been gradually supplanted by a human-being-oriented approach... It follows that in the area of armed conflict the distinction between interstate wars and civil wars is losing its value as far as human beings are concerned". ${ }^{62}$ The Appeal Chamber discussed the applicable laws and identified:

"such areas as protection of civilians from hostilities, in particular from indiscriminate attacks, protection of civilian objects, in particular cultural property, protection of all those who do not (or no longer) take active part in hostilities, as well as prohibition of means of warfare proscribed in international armed conflicts and ban of certain methods of conducting hostilities"63

as coming within customary law applicable in a non-international armed conflict.

Garraway comments on the move for the law of non-international armed conflict to move closer to the law of international armed conflict through customary law and discusses the Statute of the International Criminal Court, the ICRC Customary International Humanitarian

\footnotetext{
${ }^{59}$ Ibid., p.555.

${ }^{60} \mathrm{C}$ Droege, n 3 supra p. 527

${ }^{61} \mathrm{~F}$ Hampson n 58 supra p.565 and see the concern of C Droege on this issue in C Droege: The interplay between international humanitarian law and international human rights law in situations of armed conflict. Israel Law Review Vol 40 (2007) 310-355 pp. 350-351.

${ }^{62}$ Prosecutor v Tadić (Decision on the Defence Motion for Interlocutory Appeal on Jurisdiction) ICTY-94-1 (2 October 1995) para. 97.

${ }^{63}$ Ibid., para. 127.
} 
Study and the San Remo Manual on the Law of Non-International armed conflict in contributing to this. ${ }^{64}$ Hill-Cawthorne explains that "an important driver in these developments was the parallel emergence and consolidation of human rights protections at the international level". ${ }^{65}$

Notwithstanding the approach above, human rights bodies have started to pull in the opposite direction, rather than to work on expanding IHL in non-international armed conflicts through customary international law to reflect more of the law of international armed conflict, to hold the State to applicable human rights law in a non-international armed conflict. HillCawthorne comments that this came about because of the development of human rights and the consensus that they applied during armed conflicts. ${ }^{66}$ The ICRC guidance on taking a direct part in hostilities seems to pull in two directions at once. ${ }^{67}$ On the one hand it introduces the concept of 'continuous combat function' a status-based concept which applies to civilians in a non-international armed conflict and so is closer to the law of international armed conflict, rather than the conduct-based approach that would reflect human rights law, ${ }^{68}$ yet on the other hand it assumes that IHL already requires the restraint of capture rather than kill if possible and also comments that "its conclusions remain without prejudice to additional restrictions on the use of force, which may arise under other applicable frameworks of international law such as, most notably, international human rights law...". 69

Prud'homme suggests that human rights could be applied contextually, suggesting that "the type of conflict, the type of protected person and the type of right (derogable or nonderogable) can... form strong criteria on which to construe a framework capable of clarifying the interplay between disciplines" and goes on to suggest that closer to the combat zone IHL would apply and "the close one is to non-international armed conflict and peace-time situations" the greater the argument to apply human rights law. ${ }^{70}$ However, Sassòli and Olsen express concern that this sort of sliding scale for the application of IHL and HR would lead to "much uncertainty in border-line situations". ${ }^{71}$

\footnotetext{
${ }^{64}$ C Garraway, n 26 supra p.504.

${ }^{65}$ L Hill-Cawthorne, n 30 supra p. 308.

${ }^{66}$ Ibid., p.323.

${ }^{67} \mathrm{~N}$ Melzer: Interpretive Guidance on the Notion of Direct Participation in Hostilities under International Humanitarian Law. ICRC, Geneva 2009.

${ }^{68}$ Ibid., pp. 33-36.

${ }^{69}$ Ibid., p. 82.

${ }^{70}$ N Prud'homme, n 36 supra p. 391.

${ }^{71}$ M Sassòli and L Olsen, n 49 supra p.627.
} 


\section{Conclusion}

The use of human rights bodies to deal with conflict issues is not a panacea to those wishing to rely on it after violations of IHL, even where there is a clear overlap. Most human rights bodies require exhaustion of domestic remedies prior to hearing a case. ${ }^{72}$ In the UK this has meant a flurry of litigation related to Iraq and one well-known case, Serdar Mohammed, from Afghanistan. ${ }^{73}$ These cases demonstrate the problem that, in the main, neither national judges hearing arguments under human rights law or international judges from regional or global human rights bodies have any experience of armed conflict or much knowledge of IHL. ${ }^{74}$ As Hampson states "Litigation may be an acceptable way of working out specific answers to specific questions" but it is "a remarkably arbitrary and haphazard way of working out a general issue, such as the relationship" between HR and IHL. ${ }^{75}$ She also opines that human rights is "principally designed to be applied after the event" whereas IHL "is principally designed to be applied at the time a decision is taken" and comments that it cannot be as "fine-tuned to the particular situation as can human rights law". ${ }^{76}$ Droege takes a more positive view of the role of human rights bodies commenting that bringing alleged victims of violations of HR and IHL before such bodies "is not in conflict with humanitarian law, but can indeed strengthen compliance with it, albeit through the lens of human rights law". ${ }^{77}$

Clearly the two regimes operate in the same legal space and whilst they have similarities, they are very different regimes and whilst one is binding on soldiers on the battlefield, the other only binds States. As there is currently no IHL individual petition, it has been left to national judges and human rights bodies to interpret 'human rights in an armed conflict' with little or no experience of armed conflicts or IHL. Although there are benefits to this relationship, in that human rights bodies can encourage States to comply with IHL, and put mechanisms in place to ensure that those who may breach IHL are properly investigated.

\footnotetext{
72 See Article 35(1) ECHR, Article 5(b) Optional Protocol to the International Covenant on Civil and Political Rights of 16 December 1966, 999 UNTS 171 and Article 46(1)(a) American Convention on Human Rights.

${ }^{73}$ See for example: Rahmatullah (No 2) (Respondent) v Ministry of Defence and another (Appellants)Mohammed and others (Respondents) $v$ Ministry of Defence and another (Appellants) Judgment of the Supreme Court, 17 January 2017 [2017] UKSC 1; Al-Skeini and others (Respondents) v. Secretary of State for Defence (Appellant) Al-Skeini and others (Appellants) v. Secretary of State for Defence (Respondent) (Consolidated Appeals) House of Lords Judgment, 13 June 2007 [2007] UKHL 26 and Abd Ali Hameed AlWaheed (Appellant) v Ministry of Defence (Respondent) Serdar Mohammed (Respondent) v Ministry of Defence (Appellant) Supreme Court Judgment 17 January 2017, [2017] UKSC 2.

${ }^{74}$ Although see comment on this issue by C Droege, $\mathrm{n} 3$ supra p.544.

${ }^{75}$ F Hampson, n 58 supra p. 559.

${ }^{76}$ Ibid., pp. 561-562.

${ }^{77}$ C Droege, n 3 supra p.546.
} 
Finally, with respect to lex specialis Prud'homme's warning that "the broadness of this principle allows manipulation of the law, a manoeuvring of the law that supports diametrically opposed arguments" from supporters for and against the "compartmentalization" of IHL and HR, should be taken seriously. ${ }^{78}$ Precisely because of the dangers of the use of lex specialis, its use should be avoided. To conclude, IHL and HR should not be integrated into what Lubell calls a "genetically modified mutation", in his words "Each of these bodies has unique advantages in particular circumstances and we must take care not to lose these advantages in the course of our search for smoother coapplication". 79

\footnotetext{
${ }^{78}$ N Prud'homme, n 36 supra p. 383.

${ }^{79}$ N Lubell: Parallel application of international humanitarian law and international human rights law: An examination of the debate. Israel Law Review Vol 40 (2007) 648-660, p.655.
} 